\title{
Influence of Seed Grading and Specific Gravity Separator on Seed Quality Parameters of Soybean var. DSb-21
}

\author{
Vishwanath, Ravi Hunje*, R. Gurumurthy and M.V. Manjunatha \\ Department of Seed Science and Technology, \\ University of Agricultural Sciences, Dharwad-580005, Karnataka, India \\ *Corresponding author
}

A B S T R A C T

Keywords

Seed recovery, Soybean var. DSb-

21 , Seed grader, Specific gravity separator

Article Info

Accepted:

12 December 2018

Available Online:

10 January 2019
An experiment was carried out at Seed Processing Unit and Seed Quality Testing Laboratory, Seed Unit, University of Agricultural Sciences, Dharwad, to study the influence of seed grading and specific gravity separator on seed quality parameters of soybean var. DSb-21. Among the three sieve size used $3.75 \mathrm{~mm}$ recorded higher recovery $(77.60 \%)$, seed germination $(85.00 \%)$ and seedling vigour index (3293) followed by $4.00 \mathrm{~mm}(75.20 \%, 84.33 \%$ and 3179 , respectively) and 4.80 $\mathrm{mm}(66.00 \%, 81.67 \%$ and 3016 , respectively) over other sieves used under study, indicating that Seeds obtained from specific gravity separator after processing through seed grader from below recommended sieve size $-3.75 \mathrm{~mm}$ processing equipment's have great impact upgrading the seed quality.

\section{Introduction}

Soybean [Glycine $\max (\mathrm{L}$.$) Merrill] is a major$ oil seed crop of the world grown in India. The crop is also called as "Golden Bean" or "Miracle crop" of the $21^{\text {st }}$ century on account of its multiple uses. It has the highest protein (40 \%) and rich oil (20\%), lysine and vitamins A, B and D. Soybean is one of the most important economic crop of the world grown on an area 121.19 million hectares and production of 336.62 million tonnes with productivity of 2.78 tonnes per ha (Anon., 2017). Quality seed plays a vital role in sustainable agricultural production. The genetic purity, physical purity, viability, vigour and uniformity in seed size are important parameters to determine the quality of seed. The harvested seed lot contains impurities, immature and damaged seeds. Seed size is also positively correlated to seed vigour.

Uniformity in size and constituents of seed lot were emphasized for precision sowing as well as better crop establishment (Bishaw and Vangastel, 1996). Mechanical seed processing improves physical purity as well as grade the 
seed according to size and specific gravity. This also improves the test weight, germination and vigour. Post-harvest processing machineries and their adjustments affected seed quality in soybean and most of the seed crops like chickpea (Sinha et al., 2009), green gram, black gram, soybean, sunflower (Bansal and Lohan, 2009). With advent of new improved varieties and hybrids, it is advisable to check various seed processing machines with different screen sizes to find out its impact on seed recovery and upgradation in seed lot quality.

The ability of the seed processing in getting seeds free from inert material, weed seeds and other species depends largely on the arrangement, order and choice of the cleaning and separation equipment used during processing. Transport equipment (elevators and conveyor belts) must be well chosen and dimensioned as it directly affects the quality of the seeds and may increase the mechanical damage (Oliveira et al., 1999), may allow or prevent the occurrence of mechanical mixing and affect field performance. In general, for the processing of soybean seeds the following equipment are used: pre-cleaning machine, dryer, air-screen machine (cleaning machine), spiral separator, size grader and gravity separator.

The size grader is equipment composed of several flat perforated metal plates with round holes that sorts seeds by size (width). The soybean seed varies greatly in size among different cultivars and within each cultivar. Uniformity of size in soybean seed allows the correct adjustment of the plant population in the field.

The presently recommended sieve size i.e. $4.00 \mathrm{~mm}$ for grading soybean seed is based on old varieties which are out of cultivation in seed production chain and moreover this sieve is not matching with any of the high yielding varieties which are under cultivation. The sieve size recommended for processing different crop seeds under the minimum seed certification standard appear more general and not appropriate for all the newer varieties resulting in poor seed recovery.

Gravity separators or gravity separator tables are equipment widely used in the seed industry, because they improve the quality by removing from the batch damaged, diseased, broken seeds, seeds attacked by insects or pathogens and other unwanted materials that are generally lighter than the suitable seeds (Peske et al., 2012). The gravity separator removes the seeds of lower density and, therefore, positively influences the physical and physiological quality of the seed batch. The adjustments made to the gravity separator are loading, lateral and longitudinal inclinations, air flow, the vibration movement and fractionation of the load terminal axis. The seeds of different densities separated spouts out through the gravity separator output (Santos-Neto et al., 2012). This study aims to assess the influence of isolated and combination of equipment used during the flow of the processing on the physical and physiological quality of seed batches of soybean cultivar. With this objective the present investigation was carried out.

\section{Materials and Methods}

The experiment was conducted to study the influence of seed grading and specific gravity separator on seed recovery and quality of soybean Var. DSb-21 using different sieve sizes in seed grader and the good seeds obtained from different size grading were processed through specific gravity separator at Seed Processing Unit, Dharwad. The experiment consisted of following treatments namely., $\mathrm{T}_{1}$ : Seeds obtained from specific gravity separator after processing through seed grader from recommended sieve size -4.00 
mm (Heavy), $\mathrm{T}_{2}$ : Seeds obtained from specific gravity separator after processing through seed grader from recommended sieve size - 4.00 $\mathrm{mm}$ (Medium), $\mathrm{T}_{3}$ : Seeds obtained from specific gravity separator after processing through seed grader from recommended sieve size - $4.00 \mathrm{~mm}$ (Light), $\mathrm{T}_{4}$ : Seeds obtained from specific gravity separator after processing through seed grader from below recommended sieve size - $3.75 \mathrm{~mm}$ (Heavy), $\mathrm{T}_{5}$ : Seeds obtained from specific gravity separator after processing through seed grader from below recommended sieve size - 3.75 $\mathrm{mm}$ (Medium), $\mathrm{T}_{6}$ : Seeds obtained from specific gravity separator after processing through seed grader from below recommended sieve size - $3.75 \mathrm{~mm}$ (Light), $\mathrm{T}_{7}$ : Seeds obtained from specific gravity separator after processing through seed grader from above recommended sieve size - $4.80 \mathrm{~mm}$ (Heavy), $\mathrm{T}_{8}$ : Seeds obtained from specific gravity separator after processing through seed grader from above recommended sieve size - 4.80 $\mathrm{mm}$ (Medium), $\mathrm{T}_{9}$ : Seeds obtained from specific gravity separator after processing through seed grader from above recommended sieve size - $4.80 \mathrm{~mm}$ (Light) and $\mathrm{T}_{10}$ : Unprocessed seeds (Bulk seed) as control which was laid out in Completely Randomized Design with three replications. The seeds that retained on the screen were collected separately and there quality parameters were evaluated at Seed Quality and Research Laboratory, National Seeds Project, University of Agricultural Sciences, Dharwad during 2017-18.

The Seed germination percentage was worked out as per the procedure given by ISTA (Anon., 2011), shoot and root length was measured in $\mathrm{cm}$, seedling vigour index was worked out as per the formula given by Abdul-Baki and Anderson (1973), electrical conductivity of seed leachate by Presley (1958) and Physical purity was determined by procedure given by ISTA (Anon., 2011).
Whereas, the Seed recovery percentage due to various grading methods were determined by using the following formula and expressed in percentage.

Seed recovery $(\%)=$

Weight of seeds obtained after processing $\times 100$

Weight of seeds obtained after processing

The data collected in respect of various parameters on seed quality attributes, were analyzed statistically as described by Gomez and Gomez (1984).

\section{Results and Discussion}

The seed recovery differed due to seed grading and specific gravity separator, significantly higher seed recovery was recorded in, seeds graded with $3.75 \mathrm{~mm}$ sieve size $(77.60 \%)$ which is followed by seeds graded with $4.00 \mathrm{~mm}(75.20 \%)$ sieves. Whereas, in $4.80 \mathrm{~mm}$ sieve least seed recovery per cent was recorded $(66.00 \%)$ (Table 1). The seeds graded with $3.75 \mathrm{~mm}$ sieve size recorded higher seed recovery of 77.60 per cent compared to seeds graded with $4.00 \mathrm{~mm}$ and $4.80 \mathrm{~mm}$ sieve. The reduction in seed recovery in 4.00 and $4.80 \mathrm{~mm}$ may be due to bold and bigger in seed size than seeds retained on $3.75 \mathrm{~mm}$ sieve and presence of more amounts of small seeds in seed lot. As graded good seeds are processed through specific gravity we will get three fractions and among them heavy seeds are used for quality analysis so recovery percent was much less in this machine combination.

The physical purity differed significantly due to seed grading and specific gravity separator, significantly higher physical purity was recorded in, $\mathrm{T}_{4}$ [seeds graded with $3.75 \mathrm{~mm}$ (heavy) sieve size (99.68\%)] which is on par with $\mathrm{T}_{1}$ and $\mathrm{T}_{7}$ [seeds graded with $4.00 \mathrm{~mm}$ 
(heavy) (99.55 \%) and $4.80 \mathrm{~mm}$ (heavy) $(99.43 \%)$ sieves respectively] whereas, $\mathrm{T}_{9}$ [rejected (light) seed lot of $4.80 \mathrm{~mm}$ sieve] exhibited significantly lower physical purity $(74.42 \%)$ (Table 2). The variation in physical purity may be due to the removal of shrivelled seeds, soil particles, other impurities during processing, which otherwise might not have been possible during threshing. As good seeds obtained in seed grader are processed here, the seed which are heavy has higher physical purity whereas, more impurities i.e. less physical purity observed in rejected, medium and light seed lots. Similar observations of improved physical purity have been reported by Ganiger et al., (2016) in greengram and soybean and Gagare et al., in soybean.

The test weight differed significantly due to seed grading and specific gravity separator, significantly higher test weight was recorded in $\mathrm{T}_{4}$ [seeds graded with $4.80 \mathrm{~mm}$ sieve size $(11.16 \mathrm{~g})$ (heavy)] which is followed by [seeds graded with $4.00 \mathrm{~mm}$ (heavy) (10.63 g) sieves] whereas, $\mathrm{T}_{6}$ [rejected (light) seed lot of $3.75 \mathrm{~mm}$ (heavy)] sieve exhibited significantly lower test weight $(9.1 \mathrm{~g})$ (Table 2). The test weight differed significantly due to seed grading and specific gravity separator. The higher test weight in $\mathrm{T}_{6}$ [seeds graded with $4.80 \mathrm{~mm}$ sieve size (11.16 g)] might be due to its larger seed size and more reserve food in seed as compared over rest of treatments. As good graded seeds are passed through specific gravity separator it separates or processes seeds based on weight and specific gravity, so heavy seeds which collected at first fraction have higher test weight than collected at next two fractions (medium and light). As the screen size increases during grading test weight increases indicating the positive association of seed size and seed weight [Ganiger et al., (2016) in greengram and Kausal et al., (2008) in soybean]. Significantly higher germination percentage was recorded in $\mathrm{T}_{4}$ [seeds graded with $3.75 \mathrm{~mm}$ (heavy) sieve size $(85.00 \%)$ ] which is on par with $\mathrm{T}_{1}$ [seeds graded with $4.00 \mathrm{~mm}$ (heavy) (84.33 $\%)$ and $4.80 \mathrm{~mm}$ (heavy) (81.67\%) sieves] whereas, rejected (light) seed lot of $4.80 \mathrm{~mm}$ exhibited lower germination percentage $(59.67$ $\%$ ) (Table 2). Variation in germination within sieve size used may be due to controlled conditions in germination chamber than during field emergence. According to Negi et al., (1998) large seeds had more breaks in embryonic axis and other important seed parts than the small seeds had and therefore showed poor germination and viability. Small seeds had better germination uniformity and getting more faster reserves than larger ones to seedlings in soybean cv. Katul (Rastegar and Kandi, 2011). Viability per cent also recorded highest in seeds processed through $3.75 \mathrm{~mm}$ sieve than 4.00 and $4.80 \mathrm{~mm}$ which might be due to smaller seed size and less mechanical damage. Jose et al., (2016) reported that as mechanical damage increases the viability and vigour deceases in soybean.

Table.1 Influence of seed grading and specific gravity separator on seed recovery of soybean

\begin{tabular}{|c|c|c|c|c|}
\hline \multirow{2}{*}{ Sieve size (r) } & \multicolumn{4}{|c|}{ Seed recovery } \\
\cline { 2 - 5 } & Good (kg) & Rejected (medium) (kg) & Rejected (light) (kg) & Percentage (\%) \\
\hline $\mathbf{4 . 0 0} \mathbf{~ m m}$ & 376.00 & 71.00 & 23.70 & 75.20 \\
\hline $\mathbf{3 . 7 5} \mathbf{~ m m}$ & 388.00 & 66.00 & 26.20 & 77.60 \\
\hline $\mathbf{4 . 8 0} \mathbf{~ m m}$ & 330.00 & 74.70 & 18.50 & 66.00 \\
\hline
\end{tabular}


Table.2 Influence of seed grading and specific gravity separator on physical purity, test weight, germination, shoot length, root length, seedling vigour index-I, seedling dry weight and and electrical conductivity of soybean

\begin{tabular}{|c|c|c|c|c|c|c|c|c|}
\hline $\begin{array}{c}\text { Treatmen } \\
\mathbf{t}\end{array}$ & $\begin{array}{c}\text { Physical } \\
\text { purity }(\%)\end{array}$ & $\begin{array}{l}\text { Test } \\
\text { weight } \\
\text { (g) }\end{array}$ & $\begin{array}{c}\text { Germinat } \\
\text { ion }(\%)\end{array}$ & $\begin{array}{c}\text { Shoot } \\
\text { length }(\mathrm{cm})\end{array}$ & $\begin{array}{l}\text { Root } \\
\text { length } \\
(\mathrm{cm})\end{array}$ & $\begin{array}{l}\text { Seedling dry } \\
\text { weight (mg) }\end{array}$ & $\begin{array}{l}\text { Seedling vigour } \\
\text { index-I }\end{array}$ & $\begin{array}{c}\text { Electrical } \\
\text { conductivity } \\
\left(\mathbf{d S ~ m} \mathbf{~ m}^{-1}\right)\end{array}$ \\
\hline $\mathbf{T}_{1}$ & 99.55 & 10.63 & 84.33 & 18.01 & 19.69 & 79.34 & 3179 & 0.793 \\
\hline $\mathbf{T}_{2}$ & 94.35 & 9.79 & 70.67 & 15.68 & 17.43 & 69.09 & 2410 & 1.263 \\
\hline $\mathbf{T}_{\mathbf{3}}$ & 82.29 & 9.21 & 61.67 & 11.26 & 13.86 & 66.93 & 1540 & 1.444 \\
\hline $\mathbf{T}_{4}$ & 99.68 & 10.39 & 85.00 & 18.10 & 20.65 & 78.00 & 3293 & 0.780 \\
\hline $\mathbf{T}_{5}$ & 94.69 & 9.81 & 72.67 & 16.06 & 16.65 & 68.17 & 2310 & 1.230 \\
\hline $\mathbf{T}_{6}$ & 76.14 & 9.10 & 62.67 & 11.72 & 14.09 & 65.85 & 1618 & 1.422 \\
\hline $\mathbf{T}_{7}$ & 99.43 & 11.16 & 81.67 & 17.43 & 19.51 & 80.18 & 3016 & 0.801 \\
\hline $\mathbf{T}_{8}$ & 91.44 & 9.84 & 67.33 & 15.65 & 16.19 & 68.27 & 2143 & 1.276 \\
\hline $\mathbf{T}_{9}$ & 74.42 & 9.00 & 59.67 & 11.26 & 13.45 & 65.53 & 1473 & 1.473 \\
\hline $\mathbf{T}_{10}$ & 94.31 & 10.12 & 77.33 & 17.03 & 18.71 & 69.28 & 2764 & 0.788 \\
\hline Mean & 90.63 & 9.91 & 72.30 & 15.21 & 17.02 & 71.06 & 2375 & 1.127 \\
\hline S. Em. \pm & 0.42 & 0.07 & 1.89 & 0.10 & 0.09 & 0.70 & 60 & 0.028 \\
\hline $\begin{array}{c}\text { C. D. @ } 1 \\
\%\end{array}$ & 1.24 & 0.20 & 5.57 & 0.31 & 0.27 & 2.08 & 177 & 0.083 \\
\hline
\end{tabular}

$\mathrm{T}_{1:}$ Seeds obtained from specific gravity separator after processing through seed grader from recommended sieve size - $4.00 \mathrm{~mm}$ (Heavy)

$\mathrm{T}_{2}$ : Seeds obtained from specific gravity separator after processing through seed grader from recommended sieve size $-4.00 \mathrm{~mm}$ (Medium)

$\mathrm{T}_{3}$ : Seeds obtained from specific gravity separator after processing through seed grader from recommended sieve size $-4.00 \mathrm{~mm}$ (Light)

$\mathrm{T}_{4}$ : Seeds obtained from specific gravity separator after processing through seed grader from below recommended sieve size - $3.75 \mathrm{~mm}$ (Heavy)

$\mathrm{T}_{5}$ : Seeds obtained from specific gravity separator after processing through seed grader from below recommended sieve size $-3.75 \mathrm{~mm}(\mathrm{Medium})$

$\mathrm{T}_{6}$ : Seeds obtained from specific gravity separator after processing through seed grader from below recommended sieve size - $3.75 \mathrm{~mm}$ (Light)

$\mathrm{T}_{7}$ : Seeds obtained from specific gravity separator after processing through seed grader from above recommended sieve size $-4.80 \mathrm{~mm}$ (Heavy)

$\mathrm{T}_{8}$ : Seeds obtained from specific gravity separator after processing through seed grader from above recommended sieve size - $4.80 \mathrm{~mm}$ (Medium)

$\mathrm{T}_{9}$ : Seeds obtained from specific gravity separator after processing through seed grader from above recommended sieve size $-4.80 \mathrm{~mm}$ (Light)

$\mathrm{T}_{10}$ : Unprocessed seeds (Bulk seed) control. 
Significantly higher shoot length $(18.10 \mathrm{~cm})$, root length $(20.42 \mathrm{~cm})$ and seedling vigour index (3293) was recorded in $\mathrm{T}_{4}$ [seeds graded with $3.75 \mathrm{~mm}$ (heavy) sieve size], when compared to $\mathrm{T}_{9}$ [rejected (light) seed lot of $4.80 \mathrm{~mm}$ sieve] $(11.17 \mathrm{~cm}, 14.37 \mathrm{~cm}$ and 2143 , respectively). However $\mathrm{T}_{4}$ was on par with $\mathrm{T}_{1}$ [seeds graded with $4.00 \mathrm{~mm}$ (heavy) sieves] (Table 2). Significantly higher shoot length, root length and vigour index in seeds graded with $3.75 \mathrm{~mm}$ sieve size is probably due to the difference in the rate of growth of seedlings, wherein the small size (seeds graded with $3.75 \mathrm{~mm}$ sieve size) seeds required less moisture than the large size (seeds graded with 4.00 and $4.80 \mathrm{~mm}$ sieve size) seeds and would have completed the process of imbibition earlier than the large size seeds (Singh et al., 1972). Thus, the seeds graded with $3.75 \mathrm{~mm}$ sieve size would have put fourth longer seedlings and higher germination resulted higher values for vigour index.

Similarly, the seedling dry weight differed significantly due to seed grading and specific gravity separator, significantly higher seedling dry weight was recorded in $\mathrm{T}_{7}$ [seeds graded with $4.80 \mathrm{~mm}$ (heavy) sieve size $(80.18 \mathrm{mg})$ ] which is on par with $\mathrm{T}_{1}$ [seeds graded with $4.00 \mathrm{~mm}$ (heavy) (79.34 mg) sieves] whereas, $\mathrm{T}_{9}$ [rejected (light) seed lot of $4.80 \mathrm{~mm}$ sieve] exhibited lower seedling dry weight $(65.53 \mathrm{mg})$ (Table 2). Higher seedling dry weight in $\mathrm{T}_{7}$ [seeds graded with $4.80 \mathrm{~mm}$ sieve size $(80.18 \mathrm{mg})$ ] may be due to the fact that the large seeds contained in them more number of cells per cotyledon in the form of reserve food material and thus had greater rates of dry matter accumulation and final dry weights (Guldan and Brun, 1985). Longer et al., (1986) concluded that the bold size seeds of two soybean cultivars Mark and Hill had higher seedling fresh weight accumulation than ungraded and small size seeds. These observations are also in confirmation with the results of Mohanrao (1993) in soybean. The electrical conductivity differed significantly due to seed grading and specific gravity separator, significantly higher electrical conductivity was recorded in $\mathrm{T}_{9}$ [rejected (light) seed lot of $4.80 \mathrm{~mm}$ sieve $(1.473 \mathrm{dS}$ $\left.\mathrm{m}^{-1}\right)$ ] which is on par with $\mathrm{T}_{3}$ [rejected (light) seed lot of $\left.4.00 \mathrm{~mm}\left(1.445 \mathrm{dS} \mathrm{m}^{-1}\right)\right]$ and $\left(\mathrm{T}_{6}\right)$ $3.75 \mathrm{~mm}$ (light) $\left(1.422 \mathrm{dS} \mathrm{m^{-1 }}\right)$ sieves whereas, $\mathrm{T}_{4}$ [seeds graded with $3.75 \mathrm{~mm}$ (heavy) sieve size] exhibited lower electrical conductivity $\left(0.780 \mathrm{dS} \quad \mathrm{m}^{-1}\right)$. McDonald (1999) revealed that seed size may influence electrical conductivity results because larger seed leak more electrolytes due to more mechanical damage than smaller seeds of equivalent quality [seeds graded with 3.75 $\mathrm{mm}$ sieve size], which results in lower electrical conductivity.

In conclusion, the processing of seed through seed grader with different sieve size followed by specific gravity separator during processing exhibited significant variation in seed quality. The higher seed germination, root length, shoot length, seedling vigour index was observed in seeds processed through $3.75 \mathrm{~mm}$ sieve and also followed by specific gravity separator compared to all other treatment combinations.

\section{References}

Abdul Baki, A. A. and Anderson, J. D. 1973. Vigour determination in soybean seed by multiple criteria. Crop Science. 13: 630633.

Anonymous. 2011. International Rules for Seed Testing (ISTA). Seed Science and Technology. 27: 175.

Anonymous. 2017. USDA, Foreign Agricultural Service of Global Analysis, Washington, DC, WAP-03-07.

Bansal, N. K. and Lohan, S. K. 2009. Design and development of an axial flow thresher for seed crops. Journal of Agricultural Engineering. 46(1): 1-8.

Bishaw, Z. and Vangastel, A. J. G. 1996. 
Components of seed quality. In: Proc. A train - the trainer's workshop. Amman, Jordan. Pp. 289-298.

Gagare, K. 2014. Mechanical damage due to different threshing and processing methods and its effect on seed quality of soybean [Glycine max (L.) Merrill]. (Doctoral dissertation, Mahatma Phule Krishi Vidyapeeth, Rahuri.).

Ganiger, B. S., Basavegowda. Lokesh, G. Y. and Rekha. 2016. Standardization of screen sizes for Green gram seed processing. The Bioscan. 11(4): 2379-2381.

Gomez, K. A. and Gomez, Z. A. 1984. Statistical Procedures for Agricultural Research. A Wiley International Science Publication, New York.

Guldan, S. J. and Brun, W. A. 1985. Relationship of cotyledon cell number and seed respiration to soybean seed growth. Crop Science. 25: 85-92.

Jose, M. G., Neves, J. A., Oliveira, H. P., Silva. Rodrigo, D. G. E., Reis, J. Z. and Antonio, R. V. 2016. Quality of soybean seeds with high mechanical damage index after processing and storage. Revista Brasileira de Engenharia Agrícola e Ambiental. 20(11): 1025-1030.

Kausal, R. T., Jeughale, G. S., Kakade, S. U. and Pravitrakar, N. R. 2008. Studies on optimum sieve size and type of screen for grading soybean seed. International Journal of Agricultural Science. 4: 59-62.

Mc Donald, M. B. 1999. Seed deterioration: Physiology, repair and assessment. Journal of Seed Science and Technology. 27: 177273.

Mohanrao, A. 1993. Influence of genotypes and seed size on seed quality, storability and field performance in soybean [Glycine max
(L.) Merrill]. M. Sc. (Agri.) Thesis, University of Agricultural Sciences, Dharwad, Karnataka (India).

Negi, H. C. S., Kant, K. and Verma, M. M. 1988. Improving germination by grading in soybeans. Seeds and Farms. 14 (7): 17-19.

Oliveria, A., Sader, R., Krzyzanowski, F. C. and Danos. 1999. Mecanicosocorridos no beneficiamento de sementes de soja e suas relações com a qualidade fisiologica. Revista Brasileira de Sementes. 21(1): 5966.

Peske, S. T., Villele, F. A. and Menghello, G. E. 2012. Sementes: fundamentos científicos e tecnológicos. Pelotas: Editora Universitária / UFPel. 3.

Rastegar, Z. and Kandi, M. A. S. 2011. The effect of salinity and seed size on seed reserve utilization and seedling growth of soybean [Glycine $\max$ (L.) Merrill. International Journal Agronomy. 2(5): 1-4.

Presley, J. J. 1958. Relations of protoplast permeability to cotton seed viability and predisposition of seedling disease. Plant Disease Report. 42: 5852.

Santos-Neto, A. L., Carvalho, M. L. M., Oliveria, J. A., Fraga, A. C. and Souza, A. A. 2012. Use of densimetric table to improve the quality of commercial castor bean seeds. Revista Brasileira de Sementes. 34(4): 549555.

Singh, J, N., Tripathi, S. K. and Negi, P. S. 1972. Note on the effect of seed size on germination, growth and yield of soybean. Indian Journal Agricultural Science. 42 (1): 83-89.

Sinha, J. P., Dhaliwal, J. S., Sinha, S. N. 2009. Effect of machine parameters on threshing quality for seed crop in chick pea. Journal of Agricultural Engineering. 46(4): 11-16.

\section{How to cite this article:}

Vishwanath, Ravi Hunje, R. Gurumurthy and Manjunatha, M.V. 2019. Influence of Seed Grading and Specific Gravity Separator on Seed Quality Parameters of Soybean var. DSb-21. Int.J.Curr.Microbiol.App.Sci. 8(01): 1707-1713. doi: https://doi.org/10.20546/ijcmas.2019.801.181 